\title{
Evaluation of Garlic (Allium sativum L.) Varieties for Bulb Yield and Growth at Dabat, Northwestern Ethiopia
}

\author{
Asrat Ayalew*, Daniel Tadesse, Zenebe G. Medhin, Solomon Fantaw \\ Department of Plant Sciences, University of Gondar, Gondar, Ethiopia \\ Email: ${ }^{*}$ gizelekullu@gmail.com
}

Received 4 January 2015; accepted 20 January 2015; published 26 January 2015

Copyright (C) 2015 by authors and OALib.

This work is licensed under the Creative Commons Attribution International License (CC BY).

http://creativecommons.org/licenses/by/4.0/

(c) (i) Open Access

\section{Abstract}

A field experiment was conducted for two consecutive years (2013 and 2014) during the dry periods under irrigation at Dabat District, Northwestern Ethiopia to select the best adaptable and high yielder varieties. Five garlic varieties (BishoftuNech, Kuriftu, Tseday 92, MM-98 and the local) were planted on randomized complete block design with three replications. Data on days to emergence, days to maturity, pseudo stem height, number of leaves per plant, bulb diameter, number of cloves per bulb, fresh bulb weight, bulb yield, and bulb dry matter content were collected and subjected to analysis of variance (ANOVA) using SAS computer software version 9.0. Mean separation test was done by list significant difference (LSD) test at $5 \%$ probability level. The results revealed that varieties were significantly differed in all parameters. BishoftuNech was early maturing variety (135 days) followed by Kuriftu (143 days). MM-98 was matured lately at 176 days after planting. Significantly highest pseudo stem height and number of leaves per plant were recorded from the local variety. Similarly, significantly highest yield of $16.56 \mathrm{t} \cdot \mathrm{ha}^{-1}$ was recorded from the local variety. MM-98 and the local variety were with the highest bulb dry matter content of 25.83 and $23.86 \%$, respectively. This research proved that the improved varieties were not compared with the local cultivar before they get released. Therefore, the result of this research can be used as good information for the future garlic variety development program at national level. Considering the most desirable yield and yield component parameters, the local variety is recommended to the producers at Dabat District. Further research on collection, characterization and evaluation of the local cultivars should be conducted for national use.

\section{Keywords}

Garlic, Varieties, Bulb Yield

Subject Areas: Agricultural Science, Plant Science

\footnotetext{
${ }^{*}$ Corresponding author.
}

How to cite this paper: Ayalew, A., Tadesse, D., Medhin, Z.G. and Fantaw, S. (2015) Evaluation of Garlic (Allium sativum L.) Varieties for Bulb Yield and Growth at Dabat, Northwestern Ethiopia. Open Access Library Journal, 2: e1216. 


\section{Introduction}

Garlic (Allium sativum L.) belongs to the family Alliaceae and genus Allium, and is a shallow rooted vegetable crop [1]. It is an ancient crop that originated in Central Asia and it has been grown for culinary, medicinal, and religious purposes for several millennia [2] [3]. The alliums are distributed widely throughout the temperate, warm temperate and boreal zones of the northern hemisphere [2].

Garlic takes one of the top places among vegetables contributing to the maintenance of good health of humans. The species has been already grown and consumed in ancient Egypt and Rome [4]. According to Goldy [5], evidence of garlic cultivation can be found as far back as 3200 BC in Egypt and it continues to be an important part of Mediterranean, European and Asian diets as a food item, as well as a medicinal plant used to treat a variety of ailments. Garlic has been known for many hundreds of years and has many beneficial qualities. It is a natural antiseptic and was used as such in the First World War [6]. Not surprisingly, in view of its strength of flavor, it is used primarily as a condiment rather than a bulk foodstuff [7]. Garlic is grown for its edible bulbs, which are composed of a number of cloves. The bulbs can be eaten fresh, cooked in various ways, processed into a dehydrated product, or saved for seed to be planted later [3].

Garlic is produced in Ethiopia mainly as a spice crop for seasoning of foods and for its medicinal values. It is widely cultivated around home gardens in Ethiopia. But nowadays, its production is practiced in some large farms. Garlic is exported to Europe, Middle East and North America [8].

Despite the crop is a high value crop, its production and productivity are very low due to production and marketing constraints. According to CSA [1], the average area covered and total production of garlic in Ethiopia are 16411.19 ha and 159093.58 tons annually. This low yield of garlic is believed to be due to lack of improved agronomic practices, lack of improved and adaptable varieties, low soil fertility, diseases, insect pests and lack of improved post harvest technologies [8].

Dabat District has a great potential to produce garlic under irrigation. But there is no any improved variety under production in the woreda. Before the execution of this research, there are no any research efforts in relation to improved agronomic practices and variety adaptation trial to fully exploit the yield potential of garlic in this woreda. Farmers use only the local varieties with their own traditional production methods. As a result, the average yield of the crop is very low in this woreda $-8 \mathrm{t}^{-h a^{-1}}$ [9]. Even if the area is very suitable and the crop is very important commercially for the farmers for income generation, productivity is still unsatisfactory. Therefore, this research was executed to select adaptable and high yielder garlic varieties under irrigation for Dabat and similar districts.

\section{Materials and Methods}

\subsection{Description of the Study Area}

The study was conducted at Dabat District of North Gondar Administrative Zone. Dabat Distric is located at 814 $\mathrm{km}$ and $75 \mathrm{~km}$ north of Addis Ababa and Gondar City, respectively. Dabat Town is the main town of the district. The neighboring districts surrounding Dabat are Debark (in the north and north east), Tsegedie (in the west), Wogera (in the south and south east). The district has a total of 28,293 ha of cultivated land and a population of 176,795. The total garlic cultivation area in the woreda is 39 ha [9].

The altitude of the woreda ranges from 1500 to 3200 meters above sea level. Mean annual rainfall in the woreda ranges from 800 to $1400 \mathrm{~mm}$. The main rainy season starts at the beginning of June and continues up to the end of September. The minimum and maximum temperature of the woreda is $18^{\circ} \mathrm{C}$ and $35^{\circ} \mathrm{C}$, respectively [9]. The experimental plot was located at $13^{\circ} 05^{\prime} \mathrm{N}$ and $37^{\circ} 50^{\prime} \mathrm{E}$ and with an altitude of 2740 meters above sea level (GPS reading).

\subsection{Material and Design}

Five garlic varieties namely, BishoftuNech, Tseday 92, Kuriftu, MM-98 and the local were laid on Randomized Complete Block Design with four replications. The number of rows per plot was 8 for each treatment; each row containing 20 plants. Cloves of medium sized (2 - $2.5 \mathrm{~g}$ ) were used as a planting material. The cloves were hand planted $10 \mathrm{~cm}$ apart on rows spaced by $25 \mathrm{~cm}$ at a depth of $3 \mathrm{~cm}$.

Nitrogen was split applied in the form of Urea at the rate of $150 \mathrm{~kg} \cdot \mathrm{ha}^{-1}$ half at planting and the other half at 30 days after planting. Phosphorus was applied in the form of DAP at a rate of $200 \mathrm{~kg} \cdot \mathrm{ha}^{-1}$ [8]. Other cultural 
practices were carried out as per the recommendations for the crop.

\subsection{Data Collection}

Data on plant height, number of leaves per plant, bulb diameter, number of cloves per bulb, bulb weight per plant and bulb dry mater content were recorded from a sample of 10 representative plants. Bulb yield was recorded from the middle 6 rows from each plot and converted into tons per hectare. Date of emergence was recorded when $50 \%$ of the plants per plot were emerged. Date of maturity was recorded when the plant was ready to harvest.

\subsection{Data Analysis}

For each treatment the mean value of the above-described parameters were computed and subjected to analysis of variance using SAS computer software version 9.0 with general linear model procedure [10]. Mean separation test was be done by List Significant Difference (LSD) test at 5\% probability level.

\section{Result and Discussion}

\subsection{Days to $50 \%$ Emergence}

Variety had a highly significant ( $\mathrm{p}<0.001)$ effect on days to $50 \%$ emergence. Variety BishoftuNech achieved $50 \%$ emergence 10 days after planting where as the local variety and Kuriftu attained their $50 \%$ emergence 12 days after planting. MM-98 was the late variety to attain 50\% emergence (Table 1 ).

\subsection{Days to Maturity}

Variety had a highly significant effect on date of maturity $(\mathrm{p}<0.001)$. BishoftuNech was early maturing variety followed by Kuriftu. MM-98 was matured lately at 176 days after planting (Table 1). The five varieties thus differed significantly in date of maturity. Similar result was reported by Yesigat (2008) on BishoftuNech and MM-98. This result is also in line with the work of Tadese [11] who reported that Tseday 92 and BishoftuNetch were matured 137 and 131 days after planting, respectively. This result revealed that BishoftuNech is early maturing variety followed by Kuriftu. On the other hand MM-98 was the late maturing variety which required 176 days to mature. This extended growth period of this variety may incur additional cost and makes the land not to be ready for the next crop.

\subsection{Pseudo Stem Height}

The pseudo stem height was significantly affected by garlic varieties $(\mathrm{p}<0.01)$. Significantly highest pseudo stem length was recorded from the local variety $(28.80 \mathrm{~cm})$ followed by Kuriftu $(24.53 \mathrm{~cm})$ and MM-98 $(24.43$ $\mathrm{cm})$. Significantly lowest pseudo stem height of $22.31 \mathrm{~cm}$ was recorded from BishoftuNech (Table 2). Therefore, this result indicated that the local variety is more vigorous than the rest of the garlic varieties.

\subsection{Number of Leaves per Plant}

Varieties had a significant effect on number of leaves per plant $(\mathrm{p}<0.01)$. Significantly highest number of leaves per plant was recorded from the local variety than Kuriftu, Tseday 92 and BishoftuNech (Table 2).

\subsection{Bulb Diameter}

Variety had a significant effect on bulb diameter $(\mathrm{p}<0.01)$. The local variety and Kuriftu scored the highest mean bulb diameter as compared to Tseday 92 and MM-98 (Table 3). As size is considered as a quality criterion for variety selection, the local variety and Kuriftu were selected by the farmers.

\subsection{Number of Cloves per Bulb}

Varieties were significantly differed in number of cloves per bulb $(\mathrm{p}<0.01)$. Significantly, highest number of cloves per bulb was recorded from the local variety (20.45) followed by Kuriftu (16.68). Tseday 92 scored 
Table 1. Days to emergence and maturity of garlic varieties at Dabat, 20132014.

\begin{tabular}{ccc}
\hline Variety & Days to $50 \%$ emergence & Days to maturity \\
Local & $12.00 \mathrm{c}$ & $145.00 \mathrm{~b}$ \\
BishoftuNech & $10.00 \mathrm{~d}$ & $135.00 \mathrm{e}$ \\
Tseday 92 & $13.00 \mathrm{~b}$ & $144.00 \mathrm{c}$ \\
Kuriftu & $12.00 \mathrm{c}$ & $143.00 \mathrm{~d}$ \\
MM-98 & $35.00 \mathrm{a}$ & $176.00 \mathrm{a}$ \\
LSD & 0.01 & 0.84 \\
CV (\%) & 0.05 & 0.03 \\
\hline
\end{tabular}

Means followed by same letters in a column are not significantly different at $\mathrm{p} \leq 0.05$.

Table 2. Mean pseudo stem height and number of leaves per plant of garlic varieties at Dabat (2013-2014).

\begin{tabular}{ccc}
\hline Variety & Pseudo stem height $(\mathrm{cm})$ & $\begin{array}{c}\text { Number of leaves } \\
\text { per plant }\end{array}$ \\
Local & $28.80 \mathrm{a}$ & $8.31 \mathrm{a}$ \\
BishoftuNech & $22.31 \mathrm{c}$ & $7.77 \mathrm{c}$ \\
Tseday 92 & $18.86 \mathrm{~d}$ & $7.07 \mathrm{~d}$ \\
Kuriftu & $24.53 \mathrm{~b}$ & $8.05 \mathrm{~b}$ \\
MM-98 & $24.43 \mathrm{~b}$ & $8.21 \mathrm{ab}$ \\
LSD & 1.23 & 0.76 \\
CV (\%) & 4.28 & 1.76
\end{tabular}

Means followed by same letters in a column are not significantly different at $\mathrm{p} \leq 0.05$.

Table 3. Yield and yield component of garlic varieties at Dabat (2013-2014)

\begin{tabular}{|c|c|c|c|c|c|}
\hline Variety & Bulb diameter $(\mathrm{cm})$ & $\begin{array}{l}\text { Number of cloves } \\
\text { per bulb }\end{array}$ & $\begin{array}{l}\text { Fresh bulb weight } \\
\text { per plant (g) }\end{array}$ & Bulb yield (t $\left.\cdot h a^{-1}\right)$ & $\begin{array}{c}\text { Bulb dry matter } \\
\text { content per plant (\%) }\end{array}$ \\
\hline Local & $5.36 \mathrm{a}$ & $20.45 a$ & $49.72 \mathrm{a}$ & $16.56 a$ & 23.86ab \\
\hline BishoftuNech & 4.75ab & $13.57 \mathrm{dc}$ & $28.15 b c$ & 9.38bc & $19.76 \mathrm{c}$ \\
\hline Tseday 92 & $4.17 \mathrm{~b}$ & $12.70 d$ & $16.70 d$ & $5.57 d$ & 15.33d \\
\hline Kuriftu & $5.35 \mathrm{a}$ & $16.68 \mathrm{~b}$ & $35.36 b$ & $11.78 \mathrm{~b}$ & $21.90 \mathrm{bc}$ \\
\hline MM-98 & $4.17 \mathrm{~b}$ & $15.00 \mathrm{bc}$ & $25.53 c$ & $8.52 c$ & $25.83 a$ \\
\hline LSD & 0.75 & 1.95 & 7.47 & 2.50 & 2.36 \\
\hline CV (\%) & 13.08 & 10.25 & 19.81 & 19.91 & 9.12 \\
\hline
\end{tabular}

Means followed by same letters in a column are not significantly different at $\mathrm{p} \leq 0.05$.

significantly lowest number of cloves per bulb (Table 3). This result revealed that the local variety is superior to the rest of the varieties for this very important yield component parameter which is the edible part of garlic.

\subsection{Fresh Bulb Weight per Plant and Yield Hectare}

Varieties were significantly differed in their fresh bulb weight per plant and yield per hectare $(\mathrm{p}<0.01)$. Significantly highest fresh bulb weight (49.72 g per plant and $16.56 \mathrm{t}^{-\mathrm{ha}^{-1}}$ ) was recorded from the local variety fol- 
lowed by Kuriftu (35.36 g per plant and $11.78 \mathrm{t} \cdot \mathrm{ha}^{-1}$ ). Significantly lowest bulb weight of $16.70 \mathrm{~g}$ per plant and $5.57 \mathrm{t}^{-h^{-1}}$ was recorded from Tseday 92 (Table 3). The mean fresh bulb yield of the local variety was 4.78, 8.04 and $10.99 \mathrm{t}^{\mathrm{b}} \mathrm{a}^{-1}$ higher than Kuriftu, MM-98 and Tseday 92, respectively. This result indicated that the local variety is superior to the nationally released varieties.

\subsection{Bulb Dry Matter Content per Plant}

Varieties were significantly differed in their bulb dry matter content per plant $(\mathrm{p}<0.01)$. Significantly, highest bulb dry matter of $25.83 \%$ was recorded from MM-98. In this parameter Tseday 92 was with the least bulb dry matter content of $15.33 \%$ (Table 3). The highest significant dry matter content of MM-98 may be confined with its long growth period by which it may uptake more essential minerals and accumulated more assimilates.

\section{Conclusion and Recommendation}

The local variety was superior in most of the desirable parameters for garlic. This research work proved that the improved and released varieties of garlic were not compared with the local cultivar which was under production in the study area before they get released. Therefore, the result of this research can be used as good information for the future garlic variety development program at national level. Finally, considering the most desirable yield and yield component parameters, the local variety should be recommended to the producers at Dabat District. Further research on collection, characterization and evaluation of the garlic cultivars which are under production in the study area and in the nearby districts with similar agro-ecologies should be conducted in order to make this variety to be registered and released at national level

\section{Acknowledgements}

We would like to thank the Office of Research and Community Service Vice President, Office of the Dean of Faculty of Agriculture, and Department of Plant Sciences, University of Gondar for funding of the project and for their technical and material support.

\section{References}

[1] CSA (2014) The Federal Republic of Ethiopia Central Statistics Authority Agricultural Sample Survey $20013 / 14$ (2006 E.C), Report on Area and Production of Major Crops. Statistical Bulletin, 532.

[2] Brewster, J.L. (1994) Onions and Other Vegetable Alliums. CAB International, Wallingford.

[3] Hannan, R.M. and Sorensen, E.J. (2001) Crop Profile for Garlic in Washington. Washington State University, Pullman.

[4] Rekowska, E. and Skupien, K. (2007) Influence of Flat Covers and Sowing Density on Yield and Chemical Composition of Garlic Cultivated for Bundle-Harvest. Vegetable Crops Research Bulletin, 66, 17-24. http://dx.doi.org/10.2478/v10032-007-0003-y

[5] Goldy, R. (2000) Producing Garlic in Michigan. Michigan State University Extension.

[6] Gene, B. (2009) Garlic. Huntington College of Health Sciences, Literature Education Series on Dietary Supplements.

[7] Purseglove, S.W. (1992) Tropical Crops, Monocotyledons. Vol. 2, Longman Group Ltd., London, 20-140.

[8] Debrezeit Agricultural Research Center (2006) Garlic Production Management. Debrezeit Agricultural Research Center, Leaflet (Amharic Version), Debrezeit, Ethiopia.

[9] Dabat Woreda Office of Agriculture and Rural Development (2010) (Unpubl) Annual Report of 2007. Dabat, Ethiopia.

[10] Tewoldebrhan, T. (2009) Participatory Varietal Evaluation and Farmer Based Seed Production: A Sustainable Approach to Garlic Seed Delivery in Atsbi Womberta Wereda, Eastern Tigray. M.Sc. Thesis, College of Dry Land Agriculture and Natural Resources, Mekelle University, Ethiopia, 61.

[11] Yesigat, M. (2008) Yield and Growth of Garlic (Allium sativum L.) Varieties as Affected by Plant Density at Wadla, North Ethiopia. M.Sc. Thesis, Univerity of Hawassa, Ethiopia, 50-74. 
Scientific Research Publishing (SCIRP) is one of the largest Open Access journal publishers. It is currently publishing more than 200 open access, online, peer-reviewed journals covering a wide range of academic disciplines. SCIRP serves the worldwide academic communities and contributes to the progress and application of science with its publication.

Other selected journals from SCIRP are listed as below. Submit your manuscript to us via either submit@scirp.org or Online Submission Portal.
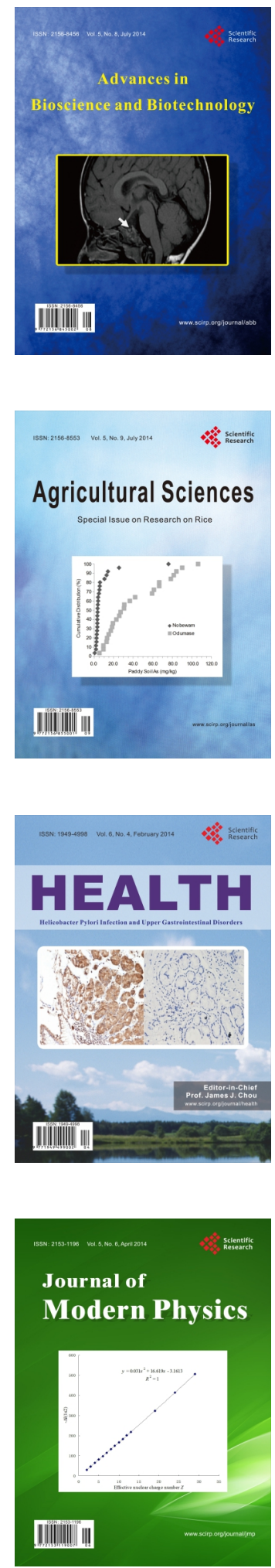
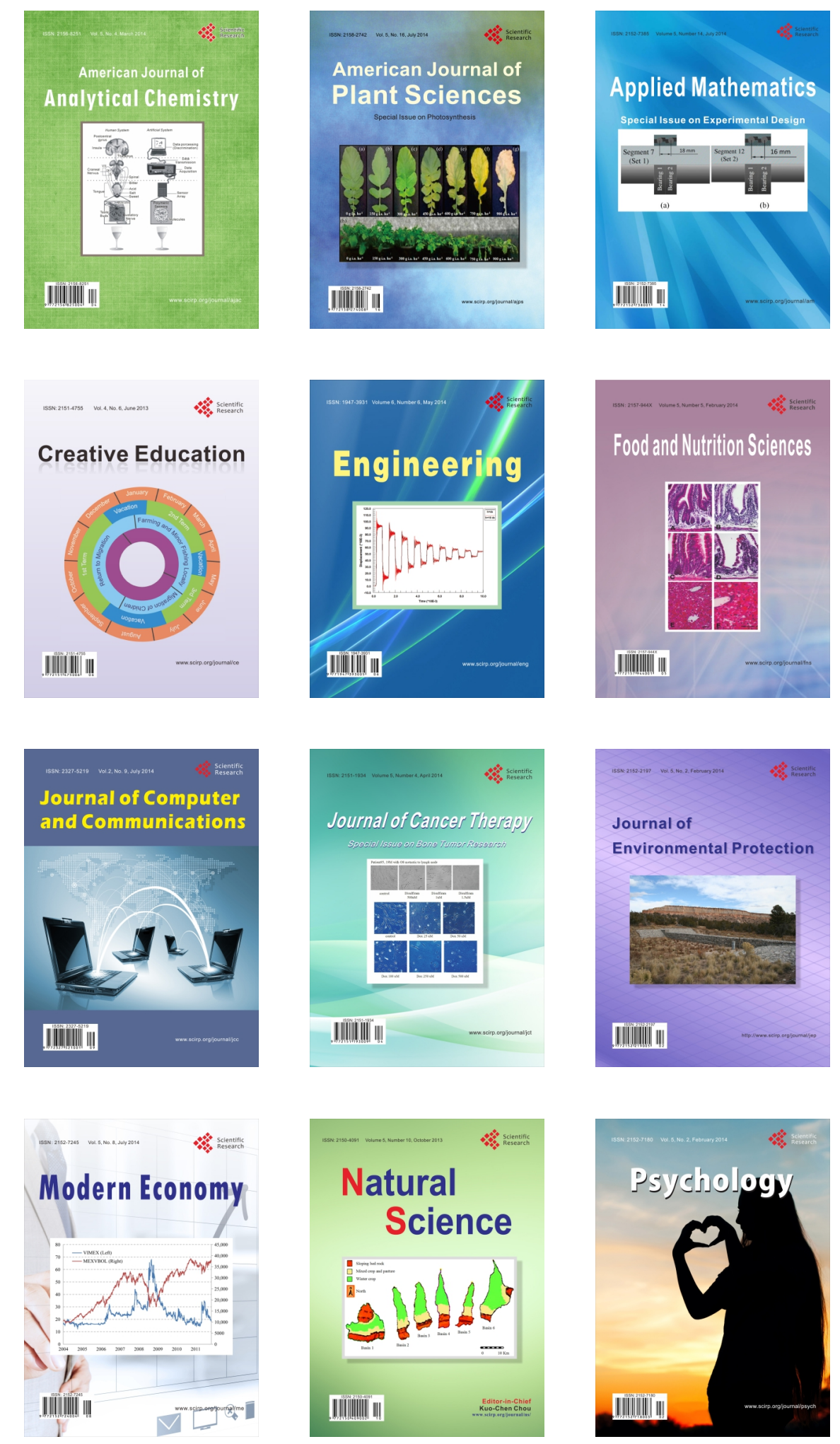